\title{
Effects of processing conditions on the texture and rheological properties of model acid gels and cream cheese
}

\author{
M. Brighenti, ${ }^{* 1}$ S. Govindasamy-Lucey, $\dagger^{2}$ J. J. Jaeggi, $\dagger$ M. E. Johnson, $\dagger$ and J. A. Lucey ${ }^{*} \dagger$ \\ *Department of Food Science, and \\ †Center for Dairy Research, University of Wisconsin, Madison 53706
}

\begin{abstract}
Manufacture of cream cheese involves the formation of an initial acid-induced gel made from high-fat milk, followed by a series of processing steps including shearing, heating, and dewatering that complete the conversion of the acid gel into a complex cheese product. We investigated 2 critical parameters for their effect on the initial gel: homogenization pressure (HP) of the highfat cheese milk, and fermentation temperature (FT). The impact of a low (10 MPa) and high (25 MPa) HP, and low $\left(20^{\circ} \mathrm{C}\right)$ and high $\left(26^{\circ} \mathrm{C}\right) \mathrm{FT}$ were investigated for their effects on rheological and textural properties of acid-induced gels. Intact acid gels were sheared and heated to $80^{\circ} \mathrm{C}$, and then their rheological properties were analyzed to help understand the effect of shearing/heating processes on the gel characteristics. The effect of HP on fat globule size distribution and the amount of protein not involved in emulsion droplets (i.e., in the bulk phase) were also studied. For cream cheese trials, a central composite experimental design was used to explore the effect of these 2 parameters (HP and FT) on the texture, rheology, and sensory properties of experimentally manufactured cream cheese. Storage modulus $\left(\mathrm{G}^{\prime}\right)$ and hardness values of cream cheeses were obtained from small amplitude oscillatory rheology tests and texture profile analysis, respectively. Quantitative spectrum descriptive sensory analysis was also performed. Consistency of acid gels (measured using a penetration test) increased with an increase in FT and with an increase in HP. Although stiffer acid-induced gels were formed at high FT, after the heating and shearing processes the apparent viscosity of the samples formed at high FT was lower than those formed at low FT. For the cream cheeses, significant prediction models were obtained for several rheological
\end{abstract}

\footnotetext{
Received January 4, 2018.

Accepted March 27, 2018.

${ }^{1}$ Current address: Cargill European Food Innovation Center, Havenstraat 84, 1800 Vilvoorde, Belgium.

${ }^{2}$ Corresponding author: rani@cdr.wisc.edu
}

and textural attributes. The $\mathrm{G}^{\prime}$ values at $8^{\circ} \mathrm{C}$, instrumental hardness, and sensory firmness attributes were significantly correlated $(\mathrm{r}>0.84)$; all these attributes significantly decreased with an increase in FT, and HP was not a significant parameter in the prediction models developed for these attributes. Significant interactions were observed between the HP and FT terms for these prediction models. Higher HP increased the amount of protein adsorbed at interface of fat globules but decreased bulk phase protein content (which may be important for crosslinking this gelled emulsion system). At higher FT temperature, coarser gel networks were likely formed. The combined effect of a coarser acid gel network at high FT, and less bulk phase casein available for crosslinking the acidified emulsion gel with an increase in HP, could have contributed to the lower stiffness/firmness observed in cream cheese made under conditions of both high FT and high HP. Stickiness of cream cheese greatly increased under conditions of high FT and high HP, whereas the sensory attributes cohesiveness of mass and difficulty to dissolve decreased. This study helped to better understand the complex relationships between the initial acid-induced gel phase and properties of the (final) cream cheese.

Key words: cream cheese, homogenization pressure, fermentation temperature, texture

\section{INTRODUCTION}

Cream cheese is a soft, fresh, acid-coagulated cheese, and according to its US Standard of Identity should have a minimum fat content of $33 \%$ and a maximum moisture level of $55 \%$ (Code of Federal Regulations, 2006). In 2015, the production of cream cheese and Neufchâtel cheese in the United States totaled 397 million $\mathrm{kg}$ (876 million pounds), which puts it in fifth place in terms of US cheese production by variety/ style (IDFA, 2016). Cream cheese has a soft, spreadable texture and a creamy, mildly acidic flavor. Cream cheese is widely used as an ingredient in various types of desserts, cheesecakes, flavored spreads, appetizers, and sauces, in addition to its widespread use on bagels. 
Cream cheese has been described as a complex acidified dairy food (Sanchez et al., 1996) and also as an acidified protein-stabilized emulsion gel (Bot et al., 2007). The manufacturing process of cream cheese involves many steps, including milk pretreatments, slow acidification, acid-induced gelation, shearing/heating of the acid gel, whey separation, and curd treatments (Lucey, 2002). After standardization of the cheese milk to the desired level of fat and solids, pasteurization, and homogenization, the milk is then fermented with mesophilic cultures until $\mathrm{pH}$ values of $\sim 4.8$ to 4.5 are reached (Fox et al., 2000). The acid-induced gel is then heated and sheared before separation of part of the acid whey, which can be done by centrifugation or by UF (Schulz-Collins and Senge, 2004). The final steps involve treatment of the hot acidified curd, which includes addition of salt and stabilizers, mixing/homogenization, and packaging.

Only a few studies have been done on the effect of manufacturing conditions on the textural and rheological properties of cream cheese. A few studies investigated the effect of heat treatment of cheese milk (Coutouly et al., 2014), final $\mathrm{pH}$ of acidification (Coutouly et al., 2014), homogenization pressure (HP) of the (acidified) cheese curd (Sanchez et al., 1994a; Wendin et al., 2000; Coutouly et al., 2014), and the rate of cooling of hot cream cheese before it is packaged (Sanchez et al., 1994b). A detailed survey of the texture, rheology, and sensory properties of commercial US cream samples has been reported (Brighenti et al., 2008).

Cream cheese is made from high-fat milk (e.g., 8-14\%) that is pasteurized and homogenized. Homogenization of milk reduces the size of fat globules and greatly increases their surface area. As the concentration of native milk fat globule membrane material is not sufficient to cover all of the newly created surface area, homogenized fat globules become coated with proteins, mainly caseins (Walstra et al., 1999; Wilbey, 2002). The casein-covered fat globules behave as active filler particles and thereby increase the effective protein concentration in milk (Fox et al., 2000). Native milk fat globules are considered inert fillers in acid gel networks (van Vliet, 1988). Upon acidification, the caseincovered fat globules become active fillers (van Vliet, 1988) and are incorporated into the gel and reinforce their structure (Guinee et al., 1993). An increase in the $\mathrm{HP}$ of milk has been reported to increase the firmness of acid-induced gels containing fat (Balasubramanyam and Kulkarni, 1991; Xiong et al., 1991; Walstra et al., 1999). No studies have been done on the effect of homogenization of cheese milk on the textural properties of the resultant cream cheese.

The fermentation temperature (FT) used for the formation of acid-induced gels has a major effect on tex- ture and physical properties (Lucey, 2004). Mesophilic lactic acid bacteria are used as starter cultures, and temperatures ranging from 20 to $30^{\circ} \mathrm{C}$ are used for the fermentation of cream cheese (Lucey, 2002). Higher FT generally results in coarser acid gel networks (Guinee et al., 1993). At higher FT, hydrophobic interactions are stronger and casein molecules contract. Higher FT also results in faster acidification rates, which depends on the type of starter culture used. With mesophilic fermentations, higher FT usually result in acid-induced gels with higher firmness and (if sheared) higher viscosity (Guinee et al., 1993; Phadungath, 2003).

To our knowledge, the homogenization conditions applied to the cheese milk and the FT used to make the initial acid-induced gel do not yet appear to have been studied for their effect on the texture, rheology, and sensory properties of cream cheese. The objective of this study was to investigate the effect of these 2 processing parameters, HP and FT, on the properties of the initial acid-induced gels. A central composite experimental design was also used to explore the effect of these 2 key parameters (HP and FT) on the texture, rheology, and sensory properties of experimentally manufactured cream cheese. This experimental design would allow us to identify if there was any significant interaction between these 2 processing parameters. It is generally considered likely that the structural properties of the acid-induced gel formed during the initial step (fermentation) of cream cheese manufacture likely affects the textural attributes of the (final) cream cheese (Fox et al., 2000). An objective of this study was to verify if significant relationships were present between the rheological and textural properties of the initial acid-induced gel and those of the final cream cheese.

\section{MATERIALS AND METHODS}

\section{Acid Gel Study}

Experimental Design. For the acid gel study, we prepared combinations of the samples at the highest and lowest levels for both the HP and FT parameters of overall interest in this study to help explore the range of textures that would be created during the complete experimental design used for the cream cheese study. These 4 levels we selected were HP $=10 \mathrm{MPa}$ and FT $=20^{\circ} \mathrm{C}($ LHP-LFT $), \mathrm{HP}=25 \mathrm{MPa}$ and $\mathrm{FT}=20^{\circ} \mathrm{C}$ $\left(\right.$ HHP-LFT), HP $=10 \mathrm{MPa}$ and $\mathrm{FT}=26^{\circ} \mathrm{C}($ LHPHFT), and $\mathrm{HP}=25 \mathrm{MPa}$ and $\mathrm{FT}=26^{\circ} \mathrm{C}$ (HHPHFT). Cream cheese milks (CCM) were prepared by combining sweet cream $(\sim 35 \%$ fat $)$ and skim milk to a fat content of $\sim 11 \%$ and a casein:fat ratio of $\sim 0.20$. The standardized CCM were heated to $\sim 65^{\circ} \mathrm{C}$ and homog- 
enized in 2 stages. The pressure for the first stage of homogenization was varied from 10 to $25 \mathrm{MPa}$, whereas the pressure of the second stage was constant at $5 \mathrm{MPa}$. The CCM were then pasteurized at $77^{\circ} \mathrm{C}$ for $19 \mathrm{~s}$.

Texture Analysis of Acid Gels. The milk samples for the acid gel testing study were inoculated with $0.1 \%$ (wt/wt) mesophilic bulk culture, Flav 1 (DSM Food Specialties Cultures USA Inc., Waukesha, WI) containing Lactococcus lactis ssp. lactis, Lactococcus lactis ssp. cremoris, Lactococcus lactis ssp. diacetylactis, and Leuconostoc mesenteroides ssp. cremoris that was grown for $\sim 10 \mathrm{~h}$ in a medium (DE-PHAGE $\mathrm{pH} 100$ medium, DSM Food Specialties Cultures USA Inc.). The inoculated milks were added to $250-\mathrm{mL}$ plastic beakers where they were incubated at the desired FT. Once the $\mathrm{pH}$ of the gels reached a value $\sim 4.7$, a penetration test was done on these gels at the temperature used for fermentation using a TA.TXT2 Texture Analyzer (Texture Technologies Corp., Scarsdale, NY) equipped with a 5-kg cell. A cylindrical stainless steel flat probe with a diameter of $45 \mathrm{~mm}$ (TA-94) was introduced $30 \mathrm{~mm}$ into the gels at a speed of $1 \mathrm{~mm} / \mathrm{s}$. The parameter measured was consistency and was defined as the (total) area under the curve. Similar shaped force-deformation curves were observed for these samples.

Rheological Properties of Stirred Acid Gels. Acid gel samples were prepared as described above and when the $\mathrm{pH}$ of the gels reached $\sim 4.7$, the gels were manually stirred with a spoon. Once their structure was broken, the beakers containing the gels were placed in a water bath where they were heated from $\sim 25$ to $80^{\circ} \mathrm{C}$, which took $\sim 30 \mathrm{~min}$, while they were continuously stirred at $100 \mathrm{~s}^{-1}$ with a Maxima digital stirrer (Fisher Scientific, Pittsburgh, PA) using a 3-blade shaft (55 mm diameter).
After reaching $80^{\circ} \mathrm{C}$, part of the stirred gels was then gently loaded with a spatula onto a controlled-stress rheometer, Paar Physica UDS 200 (Anton Paar, Ashland, VA). The measuring geometry (MK 23) consisted of a cone (diameter $50 \mathrm{~mm}$ and $2^{\circ}$ angle) and plate. Vegetable oil was used to cover the exposed sides of stirred gels to prevent evaporation. A shear rate sweep ranging from 0.01 to $600 \mathrm{~s}^{-1}$ on a logarithmic scale (no time setting) was applied to the stirred gels at a temperature of $80^{\circ} \mathrm{C}$. To determine the recovery of structure of the stirred gels, another sample was loaded onto the rheometer, cooled to $5^{\circ} \mathrm{C}$, and held at $\sim 5^{\circ} \mathrm{C}$ for $1 \mathrm{~d}$ before initiating the shear rate test at $5^{\circ} \mathrm{C}$. A thin layer of vegetable oil was added to the surface to prevent dehydration.

\section{Cream Cheese Trials}

Experimental Design. For the cream cheese study, a central composite experimental design (Mullen and Ennis, 1979) was used to study the effects of HP and FT used for the cheese milks on the rheological, textural, and sensory properties of cream cheese. To analyze the effect of the independent variables (i.e., FT and HP), a 2-level factorial experimental design, augmented with 2 star points $(\alpha=1.414)$ and 3 replicates of the center points, was selected (Montgomery, 2005). Experimental conditions were repeated with 2 independent trials. The coded and actual values of the independent variables for each treatment of the design are presented in Table 1. Coded variables were related to the real units by the following equations:

$$
\text { Coded } \mathrm{FT}=\frac{\mathrm{FT}\left({ }^{\circ} \mathrm{C}\right)-23}{2},
$$

Table 1. Coded and actual values of independent variables, homogenization pressure and fermentation temperature, used to study the effect of processing on cream cheese properties using a central composite experimental design

\begin{tabular}{|c|c|c|c|c|}
\hline \multirow[b]{2}{*}{$\begin{array}{l}\text { Treatment } \\
\text { no. }\end{array}$} & \multicolumn{2}{|c|}{ Coded value } & \multicolumn{2}{|c|}{ Actual value } \\
\hline & $\begin{array}{c}\text { Homogenization } \\
\text { pressure }\end{array}$ & $\begin{array}{l}\text { Fermentation } \\
\text { temperature }\end{array}$ & $\begin{array}{l}\text { Homogenization } \\
\text { pressure }^{1}(\mathrm{MPa})\end{array}$ & $\begin{array}{c}\text { Fermentation } \\
\text { temperature }\left({ }^{\circ} \mathrm{C}\right)\end{array}$ \\
\hline 1 & -1.414 & 0 & 10.0 & 23 \\
\hline 2 & -1 & -1 & 12.2 & 21 \\
\hline 3 & -1 & 1 & 12.2 & 25 \\
\hline 4 & 0 & -1.414 & 17.5 & 20 \\
\hline 5 & 0 & 0 & 17.5 & 23 \\
\hline 6 & 0 & 0 & 17.5 & 23 \\
\hline 7 & 0 & 0 & 17.5 & 23 \\
\hline 8 & 0 & 1.414 & 17.5 & 26 \\
\hline 9 & 1 & -1 & 22.8 & 21 \\
\hline 10 & 1 & 1 & 22.8 & 25 \\
\hline 11 & 1.414 & 0 & 25.0 & 23 \\
\hline
\end{tabular}

${ }^{1}$ First stage (second stage was kept constant at $5 \mathrm{MPa}$ ). 


$$
\text { Coded } \mathrm{HP}=\frac{\mathrm{HP}(\mathrm{MPa})-17.5}{5.3} .
$$

Preparation of Cheese Milks. Cream cheese milks were prepared by combining sweet cream ( $\sim 35 \%$ fat) and skim milk to a fat content of $\sim 12 \%$ and a casein to fat ratio of $\sim 0.20$. The standardized cheese milks were heated to $\sim 65^{\circ} \mathrm{C}$ and homogenized in 2 stages according to the experimental design shown in Table 1 . The pressure of the second stage was kept constant at $5 \mathrm{MPa}$. The cheese milks were then pasteurized at $77^{\circ} \mathrm{C}$ for 19 $\mathrm{s}$ at the University of Wisconsin-Madison Dairy Plant.

Particle Size Measurement. The particle size distribution of cheese milks homogenized at different pressures was measured by laser light scattering with a Mastersizer 2000 (Malvern Instruments, Worchestershire, UK). This instrument was equipped with a red He-Ne laser beam $(633 \mathrm{~nm})$ and a blue light source (466 $\mathrm{nm})$. For the particle size distribution measurements, the corrected refractive index of milk fat of 1.458 at 633 $\mathrm{nm}$ was used, as suggested by Michalski et al. (2001). Distilled water at room temperature was used as the dispersive medium. Measurements were performed in duplicate at an obscuration value of $\sim 12 \%$. Particle sizes analysis was repeated at least 3 times, and the surface area mean and volume-weighted mean diameters $\mathrm{d}_{3,2}$ and $\mathrm{d}_{4.3}$, respectively, were recorded.

Determination of Protein in the Bulk Phase. The amount of protein not adsorbed to the milk fat globules (i.e., in the bulk or serum phase) was determined for the range of HP used in the experimental design (10 to $25 \mathrm{MPa}$ ) using a modified method from Tomas et al. (1994). The homogenized milks were stored in a refrigerator $\left(\sim 4^{\circ} \mathrm{C}\right)$ for $1 \mathrm{~d}$. The following day, $10 \mathrm{~mL}$ of milk was centrifuged at $11,000 \times g$ for 90 min to separate the fat globules from the serum phase. Centrifugation was performed at $5^{\circ} \mathrm{C}$ to solidify the fat and facilitate its removal with a spatula. The fat layer was removed and discarded. The total protein content in the bulk phase was determined by Kjeldahl method (Marshall, 1992) and expressed as a percentage of the total protein present in the starting cheese milk.

Cream Cheese Manufacture. Cream cheese was manufactured by licensed Wisconsin cheesemakers in the University of Wisconsin-Madison dairy processing plant. On each cheesemaking day, 4 square-shaped, jacketed stainless-steel open cheese vats (Stoelting LV60, Kiel, WI), with a maximum capacity of $272 \mathrm{~kg}$ of milk, were used to manufacture the cream cheeses on 8 separate days over a period of 3 mo. One hundred thirty-six kilograms of standardized, pasteurized, and homogenized (according to the HP conditions shown in Table 1) cream mixes were added to jacketed cheese vats and cooled to the appropriate FT as shown in Table 1. On each cheesemaking day, 1 batch of cheese was made using the center point treatment: $\mathrm{HP}=17.5$ $\mathrm{MPa}$ and $\mathrm{FT}=23^{\circ} \mathrm{C}$. Cheese milks were inoculated with $0.1 \%$ (wt/wt) of the mesophilic bulk culture Flav 1 and incubated at the appropriate FT. During fermentation, $\mathrm{pH}$ values of cheese milks were monitored using an Orion Sensor Link system (model PCM 500 and PCM 700, Orion Research Inc., Beverly, MA) connected to a personal computer. Once the $\mathrm{pH}$ of the cheese milks reached $\mathrm{pH} \sim 4.70$, the curd was stirred and heated in the cheese vats until the curd reached $80^{\circ} \mathrm{C}(\sim 30 \mathrm{~min})$. The acidified curd was then pumped to a cream cheese centrifugal separator (Sharples centrifuge, model DS-2, Penwalt Corporation/Sharples Stokes division, Warminster, PA) where some of the acid whey was removed. Sufficient whey was removed to achieve $\sim 55 \%$ moisture content in the separated curd, which was determined by a rapid microwave test (CEM Smart System 5 Moisture/Solids Analyzer, CEM Corporation, Matthews, NC). After separation, approximately $36 \mathrm{~kg}$ of cream cheese was obtained from $136 \mathrm{~kg}$ of cheese milk, and the curd was pumped into a jacketed swept surface holding tank (model CBP 30, Scherping Systems, Winsted, MN). Curd was constantly agitated while the temperature was held at $\sim 76^{\circ} \mathrm{C}$. Salt $(1 \%$, wt $/ \mathrm{wt})$ and xanthan gum (Satiaxane CX90 DF, Cargill Inc., Minneapolis, MN; $0.33 \%$, wt/wt) were added to the cream cheese. The moisture content of curd was rechecked, and if necessary, the moisture was adjusted to $\sim 55 \%$ by addition of separated acid whey. After mixing the curd for $\sim 25 \mathrm{~min}$, the curds were pumped into a cream cheese homogenizer (Sprinkman M3 model no. 100DJ F3 8SS, Franksville, WI) where curd was homogenized at $1.7 \mathrm{MPa}$ for both stages. Curd was hot-packaged at a temperature of $\sim 75^{\circ} \mathrm{C}$ into $2.2-\mathrm{kg}$ cylindrical plastic containers (diameter: $14 \mathrm{~cm}$, height: $19 \mathrm{~cm}$ ) and 0.9$\mathrm{kg}$ rectangular pouches (height: $6.5 \mathrm{~cm}$, width: $6.5 \mathrm{~cm}$, length: $20.5 \mathrm{~cm}$ ). Samples were stored in a refrigerated room maintained at $\sim 5^{\circ} \mathrm{C}$.

Compositional Analyses. Cheese milks were analyzed for TS using the forced-air oven method (IDF, 2010), fat by Mojonnier (AOAC International, 2000), total protein (total percentage $\mathrm{N} \times 6.35$ ) by Kjeldahl, and NPN (AOAC International, 2000) and total Ca using inductively coupled plasma emission spectroscopy (Park, 2000). Lactose was determined by an enzymatic method (AOAC International, 2000; Boehringer Mannheim Biochemicals, Mannheim, Germany).

Cream cheeses were analyzed $1 \mathrm{wk}$ after manufacture for moisture (IDF, 2004), fat (AOAC International, 2000), total protein by Kjeldahl (AOAC International, 2000), salt by the chloride electrode method (model 
926, Corning Glass Works, Medfield, MA; Johnson and Olson, 1985), total Ca using inductively coupled plasma emission spectroscopy (Park, 2000), and lactose and lactic acid (AOAC International, 2000; Boehringer Mannheim Biochemicals). The $\mathrm{pH}$ were determined by insertion of a $\mathrm{pH}$ probe $(\mathrm{pH}$ meter $420 \mathrm{~A}$, Orion Research) directly into the cheeses.

Preparation of Cream Cheese Samples for Rheology and Texture Analyses. We faced several challenges with preparing texture/rheology samples from our experimentally manufactured cream cheese. Cream cheese is soft and difficult to accurately sample into the cylindrical shapes normally used for texture/ rheology type testing. We also wanted our samples for texture/rheology testing to have undergone the same cooling profile as the rest of the cream cheese, as it is well known that the rate of cooling of the hot cream cheese affects its texture properties (Sanchez et al., 1994b). To address these concerns, we followed the following procedure. During the experimental cream cheese manufacture, at the curd packaging step, polypropylene syringes with the nozzles removed were filled with hot cream cheese. These syringes were inserted into the $2.2-\mathrm{kg}$ packaging container filled with hot cream cheese so as to cool with the rest of the cheese in the refrigerated room at $5^{\circ} \mathrm{C}$. Two types of syringes were prepared. For rheological tests, samples were prepared in 50-mL syringes (Henke-Sass Wolf GmbH; Tuttlingen, Germany) that had an internal diameter of $29 \mathrm{~mm}$. For texture profile analysis (TPA), 20-mL syringes (Becton, Dickinson and Company, Franklin Lakes, NJ) with an internal diameter of $16 \mathrm{~mm}$ were used. When samples were needed for analysis, the syringes were removed from the product container and cylindrical-shaped cream cheese was extruded out of the syringe using its plunger. Samples were then cut to the desired thickness using a sharp blade. For rheological tests, samples had a thickness of 2 to $3 \mathrm{~mm}$ and a diameter of $29 \mathrm{~mm}$, whereas samples for texture analysis had diameter and height of $16 \mathrm{~mm}$. After slicing, samples were stored at $\sim 5^{\circ} \mathrm{C}$ for at least $2 \mathrm{~h}$ to allow for structure recovery before testing their rheological or textural properties.

Dynamic Small Amplitude Oscillatory Rheology of Cream Cheese. The rheological properties of cream cheeses were determined at 2 and 4 wk after manufacture by dynamic small-amplitude oscillatory rheology as described by Brighenti et al. (2008). A controlled-stress rheometer (Paar Physica UDS 200, Physica Messtechnik, Stuttgart, Germany) was used with a 25-mm serrated parallel plate. After loading, samples were trimmed to a diameter of $25 \mathrm{~mm}$. To prevent evaporation, vegetable oil was added to the exposed sides of the sample. Samples were heated from 5 to $80^{\circ} \mathrm{C}$ and immediately cooled from 80 to $5^{\circ} \mathrm{C}$ at a rate of $1^{\circ} \mathrm{C} / \mathrm{min}$. Samples were then maintained at $5^{\circ} \mathrm{C}$ for $30 \mathrm{~min}$. A frequency of $0.1 \mathrm{~Hz}$ and a strain of $0.05 \%$ were used. The parameters measured included the storage modulus $\left(\mathbf{G}^{\prime}\right)$, and in particular the $\mathrm{G}^{\prime}$ value at $8^{\circ} \mathrm{C}$ was selected to compare the different treatments (Brighenti et al., 2008).

Texture Profile Analysis of Cream Cheese. Textural properties of cream cheeses were analyzed at 2 and 4 wk after manufacture. Texture profile analysis was performed using a TA.XT2 Texture Analyzer (Texture Technologies Corp., Scarsdale, NY) equipped with a 5 -kg load cell. Tests were performed at $5^{\circ} \mathrm{C}$ as described by Brighenti et al. (2008). Samples were compressed at a speed of $1 \mathrm{~mm} / \mathrm{s}$ twice up to $40 \%$ of their original height with a $50-\mathrm{mm}$ aluminum cylindrical probe. The parameter measured was hardness and was defined as the maximum force during the first compression. No clear fracture point was observed.

Sensory Analysis of Cream Cheese. A trained (20 h of training) sensory panel of at least 8 panelists (usually 8 to 12 ) used quantitative spectrum descriptive analysis (Meilgaard et al., 1999) to evaluate the following textural attributes of cream cheese at 2 and 4 wk after manufacture. The method described by Brighenti et al. (2008) was followed. Attributes included firmness, stickiness, cohesiveness of mass, gumminess, difficulty to dissolve, particle size, and difficulty to spread. Samples were stored at $\sim 4^{\circ} \mathrm{C}$ for at least $24 \mathrm{~h}$, and panelists tested them immediately after removal from the refrigerator. Each sample was evaluated in duplicate on 2 consecutive days. The training of the panel, the references used to quantify their intensity, as well as the preparation of samples, were previously described (Brighenti et al., 2008). The numerical intensity for each attribute ranged from 0 to 15 with at least 4 reference points, with higher numbers indicating greater intensities.

Statistical Analysis. Results were analyzed using Statgraphics program (version 5.1 plus, Manugistics, Rockville, MD). Multiple (stepwise) regression and response surface methodology (Montgomery, 2005) was used for the results from the central composite design. A second-order model was chosen to estimate the dependent variables to accurately describe the geometric slope of response surfaces. Those factors with $F$-values lower than 4 were eliminated by using the backward selection of the stepwise regression, which at first included all the variables, but then eliminated those that were insignificant so as to simplify the model. 


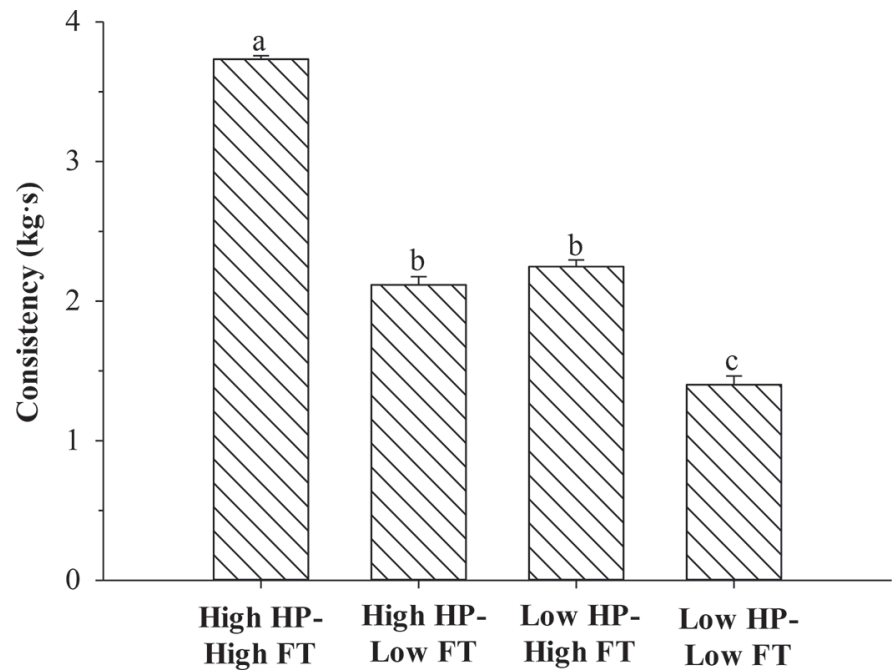

Figure 1. Consistency (area under the curve obtained from penetration test) of 4 different cream cheese gels at $\mathrm{pH}$ 4.7: high homogenization pressure (HP)-high fermentation temperature (FT; 25 MPa- $\left.26^{\circ} \mathrm{C}\right)$, high HP-low FT $\left(25 \mathrm{MPa}-20^{\circ} \mathrm{C}\right)$, low HP-high FT $(10$ $\left.\mathrm{MPa}-26^{\circ} \mathrm{C}\right)$, and low HP-low FT $\left(10 \mathrm{MPa}-20^{\circ} \mathrm{C}\right)$. Data presented were means of 3 replicates, error bars represent $\mathrm{SD}$, and different letters indicate significant $(P<0.05)$ differences.

\section{RESULTS AND DISCUSSION}

\section{Texture of Acid-Induced Gels}

The consistency of acid gels (area under the curve during penetration) was calculated for each of the 4 experimental conditions. The consistency values of acid gels increased in the following order: HHP-HFT $>$ LHP-HFT $=$ HHP-LFT $>$ LHP-LFT (Figure 1). Gels made at the same FT had a significantly $(P<0.05)$ higher consistency with the higher HP treatment, in agreement with previous reports that have indicated an increase in the firmness of acid-induced milk gels with an increase in HP (Balasubramanyam and Kulkarni, 1991; Tamime and Robinson, 1999; Ji et al., 2011). The increased consistency of acid gels with an increase in the HP was likely due to the increased fat surface area that is covered by protein, which creates more active filler particles that helped to stiffen the gel network (Lin et al., 2011).

For gels made with the same HP, a significantly $(P<$ $0.05)$ higher consistency was observed with the higher FT. At higher FT, there is an increase in hydrophobic interactions (Bryant and McClements, 1998) and at temperatures that range from 20 to $30^{\circ} \mathrm{C}$, less casein dissociation from micelles, which helps to create gels with higher firmness and viscosity (Guinee et al., 1993). Also, with higher FT, an increase occurs in thermal collisions between casein particles (Kim and Kinsella,
1989) and faster aggregation. In addition, at higher FT there is a faster acidification; very slow milk acidification was reported to produce weak gels (Lee and Lucey, 2004). Changes in the aggregation and acidification rates also likely modified the structure of acid gels (Schulz-Collins and Senge, 2004).

\section{Flow Behavior of Acid-Induced Gels}

The changes in apparent viscosity $\left(\boldsymbol{\eta}_{\text {app }}\right)$ of stirred acid gels as they were subjected to increasing shear rate are shown in Figure 2. As shear rate increased from 0.01 to $600 \mathrm{~s}^{-1}$, the $\eta_{\text {app }}$ values of stirred acid gels decreased indicating shear thinning behavior, as was expected. The $\eta_{\text {app }}$ profile of the stirred gels tested at $80^{\circ} \mathrm{C}$ and prepared using high FT $\left(26^{\circ} \mathrm{C}\right)$ was significantly $(P<$ $0.05)$ lower, at all shear rates, than the $\eta_{\text {app }}$ of gels prepared at low FT $\left(20^{\circ} \mathrm{C}\right.$; Figure 2a). This trend was also still observed even after storage of samples for $1 \mathrm{~d}$ at $5^{\circ} \mathrm{C}$ (Figure $2 \mathrm{~b}$ ). Lower values of $\eta_{\text {app }}$ indicated that greater structural breakdown occurred in gels formed at high FT during the heating/shearing process. Lee and Lucey (2006) found that yogurt gels that were formed at lower FT had higher $\eta_{\text {app }}$ values during shearing than those incubated at higher FT.

A reformation of some of the structure occurred in stirred samples after storage for $1 \mathrm{~d}$ at $5^{\circ} \mathrm{C}$, as indicated by the increase in their $\eta_{\text {app }}$ profiles (Figure $2 b$ ). In the very low shear rate region (i.e., $\leq 0.1 \mathrm{~s}^{-1}$ ), the $\eta_{\text {app }}$ values increased with an increase in shear rate before decreasing due to the structural breakdown (Figure 2). This behavior indicates the likely presence of an initial yield stress (Afonso and Maia, 2000; Lee and Lucey, 2006). At the very low shear rates used at the start of the shear rate sweep, the system was effectively acting like a low constant rate experiment, and what we observed was an overshoot type of behavior similar to previously reported for weak gels at low shear rates (Luyten et al., 1993).

\section{Composition of Milks and Cream Cheeses}

Cheese milks had TS of 19\%, fat content of $11.6 \%$, and a true protein concentration of $2.67 \%$ (Table 2). All cheese milks were standardized to a casein to fat ratio of 0.2 .

Cream cheeses with similar chemical compositions were produced to avoid possible changes in texture and rheology caused by variation in composition (Table 2). All samples met the standard of identity for full-fat cream cheese (i.e., a maximum moisture content of $55 \%$ and minimum fat content of $33 \%$; Code of Federal Regulations, 2006). 


\section{Particle Size Distribution of Cheese Milks and $\mathrm{pH}$ Profiles}

Pressure used to homogenize the standardized cheese milks had a significant effect on the volume-weighted particle diameter $\left(\mathrm{d}_{4.3}\right.$; Table 3$)$. Unhomogenized milk had a $\mathrm{d}_{4,3}$ value of $4.25 \mu \mathrm{m}$, and increasing HP significantly $(P<0.05)$ decreased the size of fat globules. At a $\mathrm{HP}$ of $25 \mathrm{MPa}$ the $\mathrm{d}_{4,3}$ value was $0.53 \mu \mathrm{m}$. The particle size distribution of the cheese milk homogenized at $10 \mathrm{MPa}$ was bimodal in agreement with previous reports (Coutouly et al., 2014) with the larger peak likely due to fat globules and the smaller peak at $\sim 0.2$
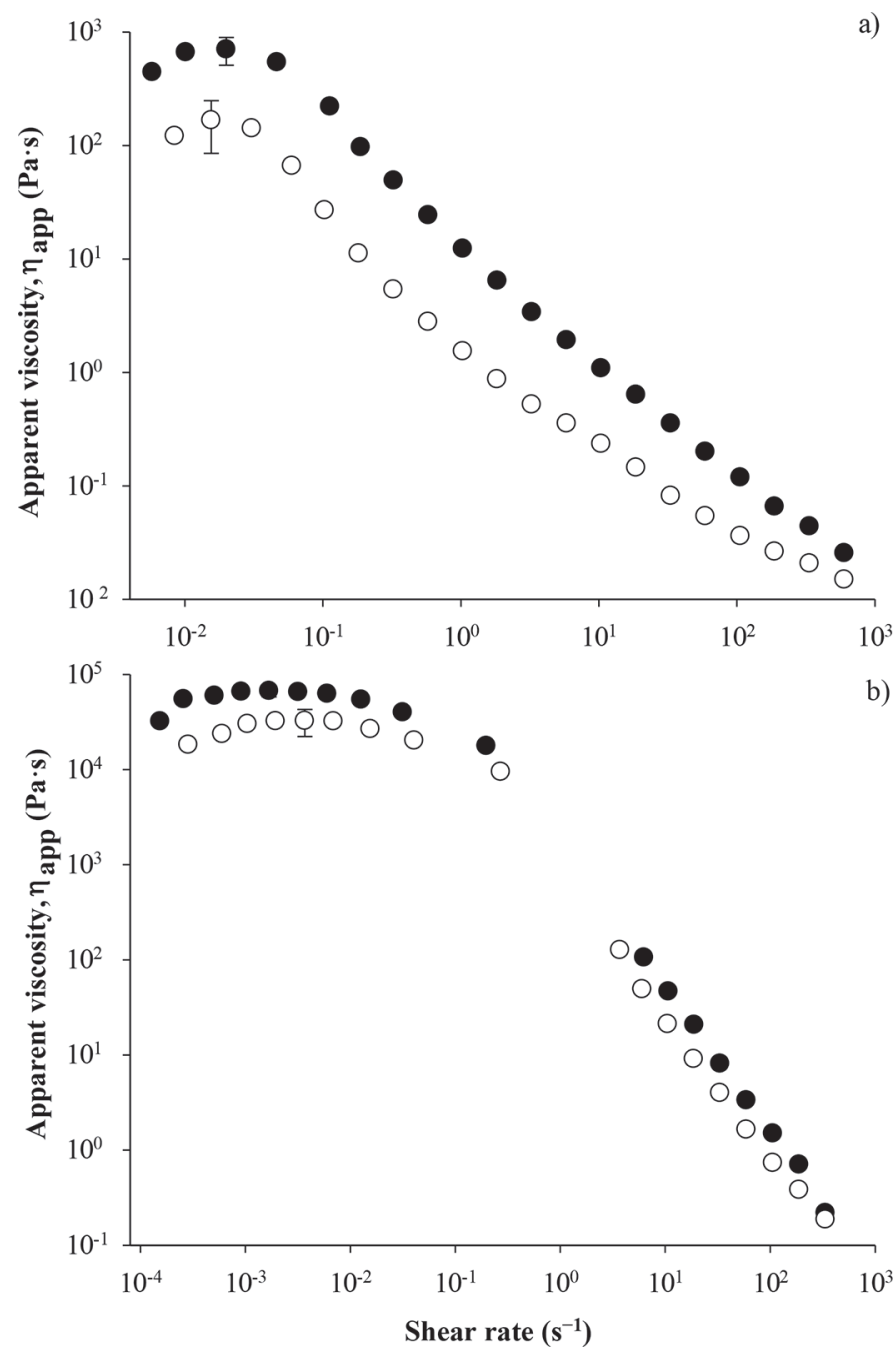

Figure 2. Apparent viscosity as a function of shear rate for stirred acid gels made from cream cheese mixes homogenized at $25 \mathrm{MPa}$ and fermented at $20(\bullet)$ and $26^{\circ} \mathrm{C}(\mathrm{O})$ and measured at (a) $80^{\circ} \mathrm{C}$ immediately after heating and stirring and (b) tested at $5^{\circ} \mathrm{C}$ after storing at $\sim 5^{\circ} \mathrm{C}$ for $1 \mathrm{~d}$. Data presented were means of 3 replicates, and error bars represent SD.
Table 2. Average $^{1}$ composition of the pasteurized cream cheese milks and experimental cream cheeses $(n=22)$

\begin{tabular}{lc}
\hline Item & Value \\
\hline Cheese milk & \\
Solids (\%) & $19.32 \pm 0.34$ \\
Fat (\%) & $11.61 \pm 0.29$ \\
Lactose (\%) & $3.72 \pm 0.75$ \\
Total protein ${ }^{2}(\%)$ & $2.84 \pm 0.05$ \\
True protein ${ }^{3}(\%)$ & $2.67 \pm 0.06$ \\
Casein $^{4}(\%)$ & $2.34 \pm 0.05$ \\
Casein:fat ratio & $0.20 \pm 0.00$ \\
Total Ca (mg/100 g) & $102 \pm 6$ \\
Cream cheese & \\
Moisture (\%) & $55.44 \pm 0.91$ \\
Fat (\%) & $33.59 \pm 1.10$ \\
Salt (\%) & $1.00 \pm 0.13$ \\
Protein $(\%)$ & $7.53 \pm 0.60$ \\
Lactose (\%) & $2.27 \pm 0.14$ \\
Lactic acid (\%) & $0.33 \pm 0.03$ \\
pH & $4.98 \pm 0.06$ \\
Total Ca (mg/100 g) & $81.1 \pm 6.7$ \\
\hline
\end{tabular}

${ }^{1}$ Means and SD of 11 treatments.

${ }^{2}$ Total $\% \mathrm{~N} \times 6.38$

${ }^{3}($ Total $\% \mathrm{~N}-\% \mathrm{NPN}) \times 6.38$.

${ }^{4}($ Total $\% \mathrm{~N}-\%$ noncasein $\mathrm{N}) \times 6.38$.

${ }^{5}$ Total $\% \mathrm{~N} \times 6.38$

$\mu \mathrm{m}$ likely to be due to (free) casein micelles (Corredig and Dalgleish, 1996; Figure 3). At HP >10 MPa no clear smaller peak was observed in the size distributions. With increasing HP, an increase occurred in the surface area of homogenized fat particles, which caused more proteins from the bulk or serum phase to adsorb at these newly created oil-water interfaces (Tomas et al., 1994; Cano-Ruiz and Richter, 1997). This increased adsorption of proteins onto the interface of homogenized fat particles resulted in a significant decrease in the bulk phase milk protein concentration (Table 3 ).

As expected, the rate of decrease in $\mathrm{pH}$ increased when cheese milks were incubated at higher FT (Figure 4 ), probably due to approach of the optimal growth temperature $\left(\sim 26^{\circ} \mathrm{C}\right)$ of the mesophilic starter culture (Cogan, 1996) that was used for acidification. Samples incubated at FT of 20 and $26^{\circ} \mathrm{C}$ took approximately 18 and $\sim 10 \mathrm{~h}$, respectively, to reach $\mathrm{pH} \sim 5.0$.

\section{Rheological and Textural Properties of Cream Cheese}

Cream cheeses were analyzed at both 2 and 4 wk after manufacture. For most samples, significant $(P<0.05)$ differences were observed between 2 and 4 wk for $G^{\prime}$ at $8^{\circ} \mathrm{C}$ and hardness by TPA (results not shown), suggesting that changes occurred in the structure/texture of cream cheeses during storage. Firmer cream cheese with a longer storage time could be due to ongoing 
Table 3. Effect of homogenization pressure on the surface area $\left(\mathrm{d}_{3,2}\right)$ and volume-weighted $\left(\mathrm{d}_{4,3}\right)$ mean $^{1}$ of particles and on the concentration of protein in the bulk phase (i.e., not adsorbed onto the homogenized fat globules) of cream cheese milks after homogenization

\begin{tabular}{lccc}
\hline Pressure $(\mathrm{MPa})$ & $\mathrm{d}_{3,2}(\mu \mathrm{m})$ & $\mathrm{d}_{4,3}(\mu \mathrm{m})$ & $\begin{array}{c}\text { Protein content of the bulk } \\
\text { phase of cheese milk }(\%)\end{array}$ \\
\hline Not homogenized & $3.46^{\mathrm{a}}$ & $4.25^{\mathrm{a}}$ & $2.84^{\mathrm{a}}$ \\
10.0 & $0.36^{\mathrm{b}}$ & $0.82^{\mathrm{b}}$ & $1.28^{\mathrm{b}}$ \\
12.2 & $0.37^{\mathrm{b}}$ & $0.80^{\mathrm{b}}$ & $\mathrm{ND}^{2}$ \\
17.5 & $0.37^{\mathrm{b}}$ & $0.70^{\mathrm{c}}$ & $\mathrm{ND}$ \\
22.8 & $0.31^{\mathrm{c}}$ & $0.57^{\mathrm{d}}$ & $0.40^{\mathrm{c}}$ \\
25.0 & $0.30^{\mathrm{c}}$ & $0.53^{\mathrm{e}}$ & \\
\hline
\end{tabular}

${ }^{\mathrm{a}-\mathrm{e}}$ Means within the same column not sharing a common superscript differ $(P<0.05)$.

${ }^{1}$ Means of 3 replicates.

${ }^{2} \mathrm{ND}=$ not determined.

(slow) fat crystallization or structural rearrangements in the cheese network. Prediction models with higher $\mathrm{R}^{2}$ values were obtained for the results of analyses performed after $4 \mathrm{wk}$ of storage; therefore, we decided to use the samples stored for 4 wk for the development of prediction models and response surface analysis.

The $\mathrm{G}^{\prime}$ values of experimental cream cheeses steeply decreased during heating up to $40^{\circ} \mathrm{C}$ and slowly decreased in the temperature range 40 to $80^{\circ} \mathrm{C}$; a maxi- mum in the loss tangent profile was observed during heating at temperatures between 20 to $30^{\circ} \mathrm{C}$ (results not shown). This rheological behavior was similar to that previously reported for commercial US cream cheese (Brighenti et al., 2008). Although $\mathrm{G}^{\prime}$ values of the cream cheeses were measured during heating from 5 to $80^{\circ} \mathrm{C}$ and subsequently cooling over this temperature range, no significant prediction models were obtained for temperatures higher than $25^{\circ} \mathrm{C}$.

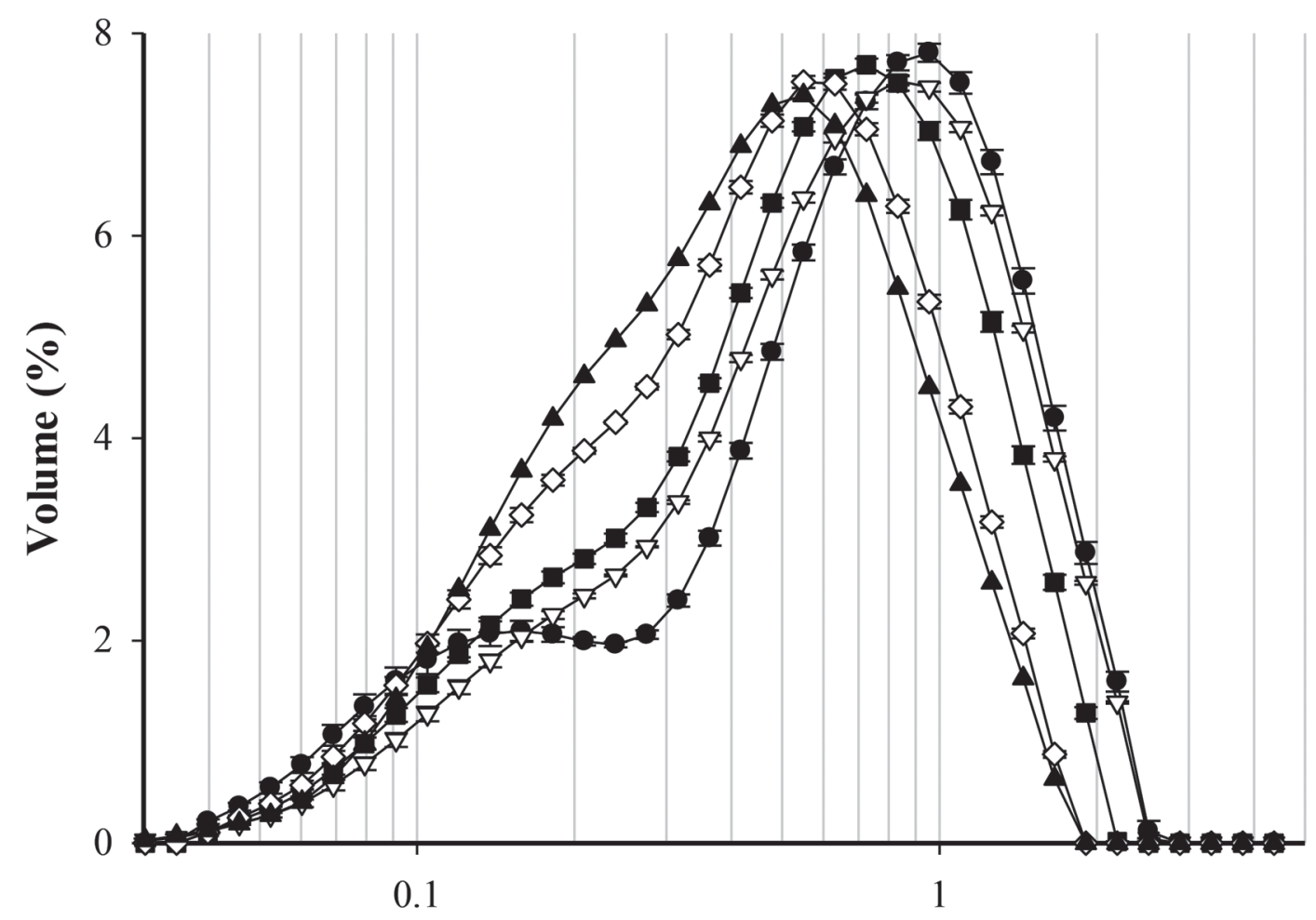

\section{Particle size $(\mu \mathrm{m})$}

Figure 3. Particle size distribution of cream cheese milks ( $\sim 12 \%$ fat) homogenized at a temperature of $\sim 65^{\circ} \mathrm{C}$ at $10(\bullet), 12.2(\nabla), 17.5(\mathbb{\square})$, $22.8(\diamond)$, and $25 \mathrm{MPa}(\mathbf{\Delta})$ during the first stage of homogenization and $5 \mathrm{MPa}$ for the second stage. Data presented were means of 3 replicates, and error bars represent SD. 


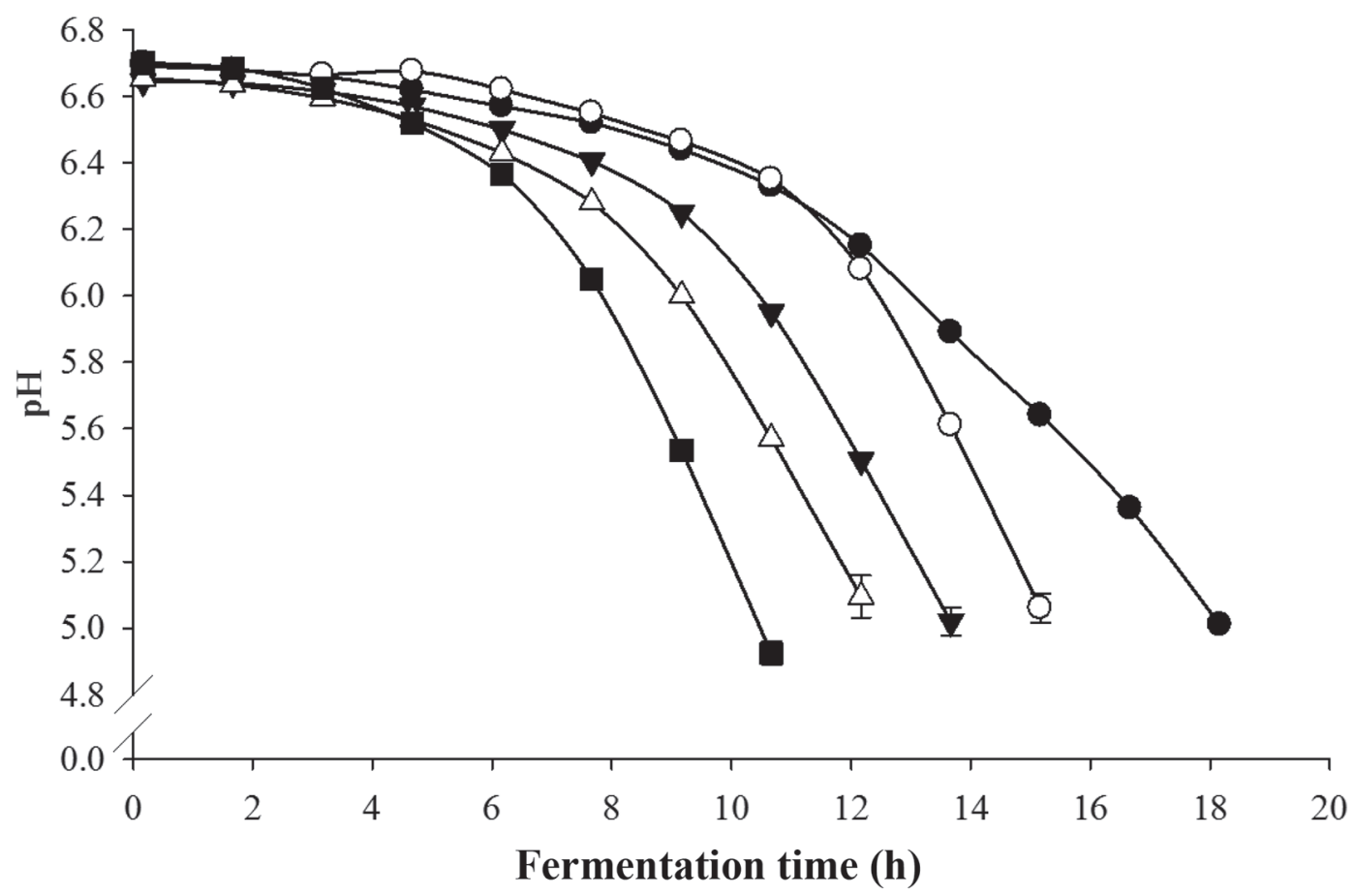

Figure 4. $\mathrm{pH}$ profiles as a function of fermentation time for cream cheese milks inoculated with $0.1 \%$ starter culture and fermented at 20 $(\bullet), 21(\bigcirc), 23(\nabla), 25(\Delta)$, and $26^{\circ} \mathrm{C}(\mathbf{\square})$. Data presented were means of 3 replicates, and error bars represent SD.

\section{Prediction Models and Response Surface Graphs}

Only prediction models for the rheological, textural, and sensory properties of experimental cream cheeses that had $\mathrm{R}^{2}$ values $>0.70$ are shown in Table 4 . Response surface graphs for $\mathrm{G}^{\prime}$ at $8^{\circ} \mathrm{C}$, hardness by TPA, and firmness from sensory test had a similar shape (Figure $5 \mathrm{a}-\mathrm{c}$ ). Highest values were observed at low FT and high HP, whereas the lowest values were observed at high FT and high HP. All these attributes $\left(\mathrm{G}^{\prime}\right.$ at $8^{\circ} \mathrm{C}$, hardness by TPA, and firmness from sensory test) significantly decreased with an increase in FT. Although initially stiffer acid-induced gels were formed at high FT (Figure 1), after heating and shearing processes, the apparent viscosity of the samples formed at high FT was lower than those formed at low FT (Figure 2), which is consistent with the results in Figure $5 \mathrm{a}-\mathrm{c}$. The HP was not a significant parameter in the prediction models developed for these attributes. Each of these dependent variables $\left(\mathrm{G}^{\prime}\right.$ at $8^{\circ} \mathrm{C}$, hardness by TPA, and firmness from sensory test) was significantly negatively affected by FT, quadratic term of FT, and by HP $\times$ FT (interaction term).

Higher HP increased the amount of protein adsorbed at the fat globules interface and decreased the bulk phase protein content (Table 3), which may be an important aspect for helping to crosslink this emulsion gel system. Coutouly et al. (2014) suggested that the use of high HP applied to the acidified cream cheese curd could result in a situation where the protein content might become limiting due to the very large increase in protein content needed to cover all the newly created homogenized fat surfaces. In this system the casein proteins are both the continuous phase (that eventually gels due to acidification) as well as the interfacial protein layer covering the emulsion droplets. We suggest that it may be possible to reach a point where most of the protein was used to create the interfacial layers on the fat droplets (because there is a high fat content and very large increase in surface area) but leaving little concentration of protein for the creation of a continuous gelled protein phase. This suggestion is in agreement with the reduced concentration of bulk phase protein in the samples subjected to very high HP.

An increase in hydrophobic interactions occurs at higher FT, which may cause contraction (reduced voluminosity) of the casein particles (Horne, 1998; Nöbel et al., 2016). At high FT, the casein particles that form the acid gels have been observed to exhibit a lower voluminosity (Darling, 1982), which could weaken the gel network by decreasing the number of interactions between caseins (Lucey, 2002). Moreover, the structure of gels formed at low FT was probably more uniform, branched, and likely had finer strands and smaller pores than those formed at high FT, as has been observed in previous studies of acid gels (Lucey et al., 1997; Lee 
and Lucey, 2004). At higher FT, a coarser gel network could exhibit greater structural breakdown during heating and shearing (Figure 2). The combined effect of a coarser acid gel network at high FT, and with an increased HP, less bulk phase casein available for crosslinking the emulsion gel, could have contributed to the lower stiffness/firmness attributes observed in cream cheese made under the conditions of high FT and high HP (Figure 5a-c).

The HP was not a significant parameter in any of prediction models developed for the dependent variables shown in Table 4. As HP was increased, the apparent concentration of pseudo-proteins also increased, which was expected to increase the number of interactions and the firmness of the cream cheeses as has been observed previously in acid-induced gels containing fat (Balasubramanyam and Kulkarni, 1991; Xiong et al., 1991; Walstra et al., 1999). The range of HP studied in this experiment was from 10 to $25 \mathrm{MPa}$, which resulted in $\mathrm{d}_{4,3}$ values that ranged from 0.82 to $0.53 \mathrm{um}$ (Table $3)$. Maybe a wider range of HP could have significantly affected cream cheese properties, such as an unhomogenized control. Coutouly et al. (2014) applied HP of up to $60 \mathrm{MPa}$ to the acidified curd and reported that very high $\mathrm{HP}$ of the cheese itself significantly affected its rheological properties. It should be noted that high HP results in smaller fat particle sizes and an increase in surface area both likely affected textural properties.

Response surface graphs for sensory attributes stickiness, cohesiveness of mass, and difficulty to dissolve are shown in Figure $5 \mathrm{~d}-\mathrm{f}$. The prediction model obtained for stickiness indicated that this property was positively affected by FT, the quadratic term of FT, and an interaction between FT and HP (Table 4). Stickiness was the only dependent variable that was positively affected by FT and thus had unique response surface curves (Figure 5d). Cohesiveness of mass and difficulty to dissolve were both significantly negatively affected by FT, quadratic term of FT, and an interaction between FT and HP (Table 4). Difficulty to spread was negatively affected by FT and an interaction between FT and HP, and positively affected by the quadratic term of HP (the only attribute that was positively affected by this term). No significant $(P>0.05)$ prediction models were obtained for the sensory attributes gumminess and particle size, which probably indicated

Table 4. Second-order polynomial models for independent variables, homogenization pressure (HP), and fermentation temperature (FT) of cream cheese milks describing the dependent variables; storage modulus at $8^{\circ} \mathrm{C}\left(\mathrm{G}^{\prime}\right.$ at $\left.8^{\circ} \mathrm{C}\right)$, hardness determined by texture profile analysis (TPA), and firmness, stickiness, cohesiveness of mass, difficulty to dissolve, and difficulty to spread determined by sensory analysis

\begin{tabular}{|c|c|c|c|c|}
\hline Dependent variable & $\begin{array}{l}\text { Independent } \\
\text { variable }\end{array}$ & Coefficient & $\begin{array}{c}\mathrm{R}^{2} \\
\text { (adjusted) }^{1}\end{array}$ & $P$-value \\
\hline $\mathrm{G}^{\prime}$ at $8^{\circ} \mathrm{C}$ & $\begin{array}{l}\text { Constant } \\
\mathrm{FT}^{* *} \\
\mathrm{HP}^{2 *} \\
\mathrm{FT}^{2 * *} \\
\mathrm{HP} \times \mathrm{FT}^{* *}\end{array}$ & $\begin{array}{r}241,167 \\
-45,947 \\
-27,639 \\
-54,526 \\
-57,175\end{array}$ & 0.88 & 0.0014 \\
\hline Hardness determined by TPA & $\begin{array}{l}\text { Constant } \\
\mathrm{FT}^{* *} \\
\mathrm{FT}^{2 *} \\
\mathrm{HP} \times \mathrm{FT}^{* *}\end{array}$ & $\begin{array}{r}955.2 \\
-136.2 \\
-124.8 \\
-192.0\end{array}$ & 0.80 & 0.0022 \\
\hline Sensory firmness & $\begin{array}{l}\text { Constant } \\
\mathrm{FT}^{*} \\
\mathrm{FT}^{2 *} \\
\mathrm{HP} \times \mathrm{FT}^{* *}\end{array}$ & $\begin{array}{r}10.73 \\
-0.53 \\
-0.58 \\
-1.06\end{array}$ & 0.82 & 0.0016 \\
\hline Sensory stickiness & $\begin{array}{l}\text { Constant } \\
\mathrm{FT}^{* *} \\
\mathrm{FT}^{2 * *} \\
\mathrm{HP} \times \mathrm{FT}^{*}\end{array}$ & $\begin{array}{l}5.97 \\
0.66 \\
0.71 \\
0.78\end{array}$ & 0.81 & 0.0019 \\
\hline Sensory difficulty to dissolve & $\begin{array}{l}\text { Constant } \\
\mathrm{FT}^{* *} \\
\mathrm{FT}^{2 *} \\
\mathrm{HP} \times \mathrm{FT}^{* *}\end{array}$ & $\begin{array}{r}10.96 \\
-0.40 \\
-0.32 \\
-0.78\end{array}$ & 0.82 & 0.0014 \\
\hline Sensory difficulty to spread & $\begin{array}{l}\text { Constant } \\
\mathrm{FT}^{*} \\
\mathrm{HP}^{2 *} \\
\mathrm{HP} \times \mathrm{FT}^{* *}\end{array}$ & $\begin{array}{r}8.82 \\
-0.47 \\
0.56 \\
-1.10\end{array}$ & 0.71 & 0.0078 \\
\hline
\end{tabular}

${ }^{1} \mathrm{R}^{2}$ values were adjusted for the degree of freedom.

$* P<0.05 ; * * P<0.01$. 

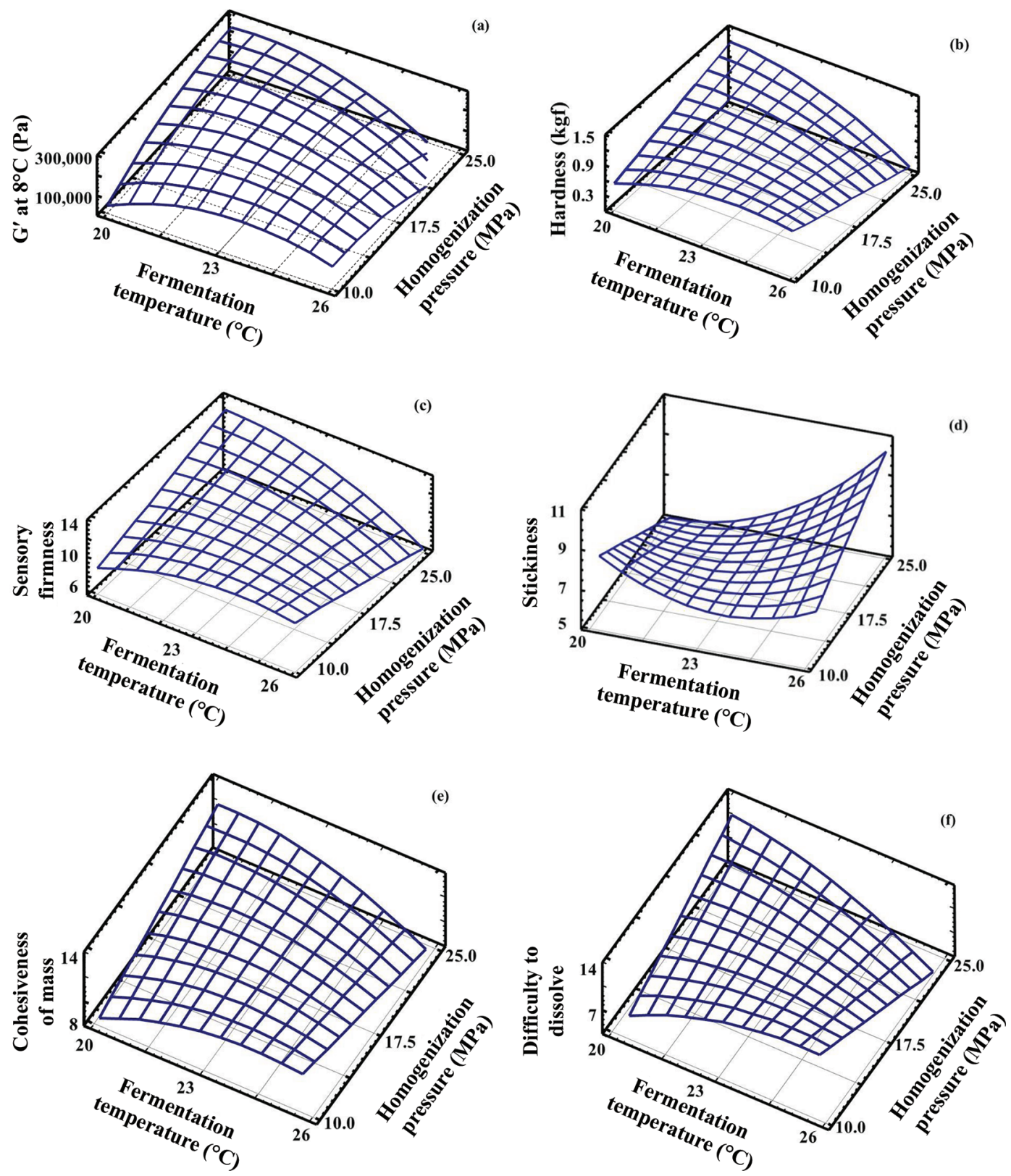

Figure 5. Response surface plots for the effects of fermentation temperature and homogenization pressure of cream cheese milks on storage modulus values at $8^{\circ} \mathrm{C}\left(\mathrm{G}^{\prime}\right.$ at $8^{\circ} \mathrm{C}$; a), hardness determined by texture profile analysis (b), firmness (c), stickiness (d), cohesiveness of mass (e), and difficulty to dissolve (f) determined by sensory analysis for cream cheese samples. Color version available online.

that the selected variables, FT and HP, did not affect these characteristics.

\section{Relationships Between Rheological, Texture, and Sensory Properties of Experimental Cream Cheese}

The $\mathrm{G}^{\prime}$ values at $8^{\circ} \mathrm{C}$, instrumental hardness and sensory firmness and cohesiveness of mass attributes, were significantly positively correlated $(\mathrm{r}>0.83$; Table 5$)$. Brighenti et al. (2008) also reported significant correlation between these parameters in their survey of commercial cream cheeses and indicated that the reason was that all of these terms are related to the strength/ number of interactions in the samples.

Stickiness of cream cheese was significantly negatively correlated $(\mathrm{r}>0.86)$ with instrumental measurements associated with hardness or stiffness (Table 5). Brighen- 
ti et al. (2008) reported that commercial cream cheeses with greater stickiness were also softer. The physical chemical basis of stickiness in food is not entirely clear. Some authors attribute it to adhesive force, some see it as being attributable to a combined effect of adhesive and cohesive forces, and others include viscosity and viscoelasticity as well (Adhikari et al., 2001). A decrease in stickiness with an increase in elasticity/hardness was also observed in other materials like pressure-sensitive adhesives and process cheese (Dahlquist, 1969; Brickley et al., 2008). Dahlquist (1969) reported that the $\mathrm{G}^{\prime}$ (index of elasticity and firmness) of an adhesive must be below $10^{5} \mathrm{~Pa}$ for adhesion to occur, which is called the Dahlquist criterion. In our study, the $\mathrm{G}^{\prime}$ at $8^{\circ} \mathrm{C}$ was $>10^{5} \mathrm{~Pa}\left(\sim 2.6 \times 10^{5} \mathrm{~Pa}\right)$ for cheeses with lowest sensory stickiness value $(\sim 5.4)$, which were manufactured using the conditions of $\mathrm{HP}=22.8 \mathrm{MPa}$ and $\mathrm{FT}=25^{\circ} \mathrm{C}$. On the other hand, the highest stickiness value of 8.6 was obtained for cheeses that were manufactured at $\mathrm{HP}=22.8 \mathrm{MPa}$ and $\mathrm{FT}=21^{\circ} \mathrm{C}$, which had $\mathrm{G}^{\prime}$ value at $8^{\circ} \mathrm{C}$ that was $<10^{5}\left(\sim 6 \times 10^{4}\right)$. Thus, our results were consistent with the Dahlquist criterion.

\section{CONCLUSIONS}

The properties of the initial acid gel affected the characteristics of the final cream cheese product made from these gels. The consistency of acid gels increased with an increase in FT and with an increase in HP. However, after heating and shearing, the apparent viscosity of the samples formed at high FT was lower than those formed at low FT. It appeared that the type of acid gel formed at high FT had different structural properties and was more susceptible to structural breakdown due to shearing. Significant prediction models were developed to describe how both FT and HP influenced the textural and rheological properties of cream cheese. All models had a high $\mathrm{R}^{2}(>0.7)$, indicating good predictive ability for describing the effects of these critical process variables on the textural attributes of cream cheese. Gels made with a combination of high HP and high FT were weaker than those gels made with a high HP and low FT, possibly due to insufficient bulk phase casein to effectively crosslink the network due to increased amount of casein absorbed at the interface with increasing HP. At high FT, caseins likely contract due to a reduced voluminosity, thus reducing contact area between the emulsion droplets. The FT used for acid-induced gelation greatly affected the textural and rheological properties of cream cheese, with higher FT causing cream cheese to be less firm, stickier, less cohesive, easier to dissolve, and more spreadable. Response surface methodology was a useful approach to 
investigate the effects of processing conditions on the properties of cream cheese.

\section{ACKNOWLEDGMENTS}

The authors thank the personnel from the Center for Dairy Research and University of Wisconsin Dairy Plant (Madison, WI) for their assistance and support in cheesemaking, analytical work, and sensory analyses. The financial support of the National Dairy Council (Rosemont, IL) is greatly acknowledged.

\section{REFERENCES}

Adhikari, B., T. Howes, B. R. Bhandari, and V. Truong. 2001. Stickiness in foods: a review of mechanism and test methods. Int. J. Food Prop. 4:1-33.

Afonso, I. M., and J. M. Maia. 2000. Rheological monitoring of structure development and rebodying of set-style yoghurt. Appl. Rheol. 10:73-79.

AOAC International. 2000. Official Methods of Analysis. Vol. 1. 17th ed. AOAC International, Arlington, VA.

Balasubramanyam, B. V., and S. Kulkarni. 1991. Standardisation of manufacture of high fat yoghurt with natural fruit pulp. J. Food Sci. Technol. 28:389-390.

Bot, A., F. A. M. Kleinherenbrink, M. Mellema, and C. K. Magnani. 2007. Cream cheese as an acidified protein-stabilized emulsion gel. Pages 651-672 in Handbook of Food Products Manufacturing. Y. H. Hui, ed. John Wiley \& Sons Inc., Hoboken, NJ.

Brickley, C. A., S. Govindasamy-Lucey, J. J. Jaeggi, M. E. Johnson, P. L. H. McSweeney, and J. A. Lucey. 2008. Influence of emulsifying salts on the textural properties of nonfat process cheese made from direct acid cheese bases. J. Dairy Sci. 91:39-48.

Brighenti, M., S. Govindasamy-Lucey, K. Lim, K. Nelson, and J. A. Lucey. 2008. Characterization of the rheological, textural, and sensory properties of samples of commercial US cream cheese with different fat contents. J. Dairy Sci. 91:4501-4517.

Bryant, C. M., and D. J. McClements. 1998. Molecular basis of protein functionality with special consideration of cold-set gels derived from heat-denatured whey. Trends Food Sci. Technol. 9:143-151.

Cano-Ruiz, M. E., and R. L. Richter. 1997. Effect of homogenization pressure on the milk fat globule membrane proteins. J. Dairy Sci. $80: 2732-2739$.

Code of Federal Regulations. 2006. Food and Drugs: CFR Part 133 Cheese and Related Cheese Products. Department of Health and Human Services, Washington, DC.

Cogan, T. M. 1996. History and taxonomy of starter cultures. Pages 1-21 in Dairy Starter Cultures. T. M. Cogan and J. P. Accolas, ed. VCH Publishers, New York, NY.

Corredig, M., and D. G. Dalgleish. 1996. Effect of different heat treatments on the strong binding interactions between whey proteins and milk fat globules in whole milk. J. Dairy Res. 63:441-449.

Coutouly, A., A. Riaublanc, M. Axelos, and I. Gaucher. 2014. Effect of heat treatment, final $\mathrm{pH}$ of acidification, and homogenization pressure on the texture properties of cream cheese. Dairy Sci. Technol. 94:125-144.

Dahlquist, C. A. 1969. Pressure-sensitive adhesives. Pages 219-260 in Treatise on Adhesion and Adhesives. Vol. 2. R. L. Patrick, ed. Marcel Dekker, New York, NY.

Darling, D. F. 1982. The effect of environmental conditions on the steric stabilization of casein micelles in milk. Pages 285-300 in Effect of Polymers on Dispersion Properties. T. F. Tadros, ed. Academic Press, London, UK.

Fox, P. F., T. P. Guinee, T. M. Cogan, and P. L. H. McSweeney. 2000. Fresh acid-curd cheese varieties. Pages $363-387$ in Fundamentals of Cheese Science. P. F. Fox, T. P. Guinee, T. M. Cogan, and P. L. H. McSweeney, ed. Aspen Publ., Gaithersburg, MD.

Guinee, T. P., P. D. Pudja, and N. Y. Farkye. 1993. Fresh acid-curd cheese varieties. Pages 363-419 in Cheese: Chemistry, Physics and Microbiology. Vol. 2: Major Cheese Groups. 2nd ed. P. F. Fox, ed. Chapman \& Hall, London, UK.

Horne, D. S. 1998. Casein interactions: Casting light on the black boxes, the structure in dairy products. Int. Dairy J. 8:171-177.

IDFA. 2016. Dairy Facts, 2016 ed. International Dairy Foods Association, Washington, DC.

International Dairy Federation. 2004. Cheese and processed cheese products: Determination of the total solids content (reference method). IDF Standard 4. International Dairy Federation, Brussels, Belgium.

International Dairy Federation. 2010. Milk, cream and evaporated milk-Determination of total solids content (reference method). IDF Standard 21. International Dairy Federation, Brussels, Belgium.

Ji, Y.-R., S. K. Lee, and S. G. Anema. 2011. Effect of heat treatments and homogenisation pressure on the acid gelation properties of recombined whole milk. Food Chem. 129:463-471.

Johnson, M. E., and N. F. Olson. 1985. A comparison of available methods for determining salt levels in cheese. J. Dairy Sci. 68:1020-1024.

Kim, B. Y., and J. E. Kinsella. 1989. Effect of temperature and $\mathrm{pH}$ on the coagulation of casein. Milchwissenschaft 44:622-625.

Lee, W.-J., and J. A. Lucey. 2004. Structure and physical properties of yogurt gels: Effect of inoculation rate and incubation temperature. J. Dairy Sci. 87:3153-3164.

Lee, W.-J., and J. A. Lucey. 2006. Impact of gelation conditions and structural breakdown on the physical and sensory properties of stirred yogurts. J. Dairy Sci. 89:2374-2385.

Lin, W., A. Marcellan, D. Hourdet, and C. Creton. 2011. Effect of polymer-particle interaction on the fracture toughness of silica filled hydrogels. Soft Matter 7:6578-6582.

Lucey, J. A. 2002. Acid and acid/heat coagulated cheese. Pages 350356 in Encyclopedia of Dairy Sciences. H. Roginski, J. W. Fuquay, and P. F. Fox, ed. Academic Press, London, UK.

Lucey, J. A. 2004. Formation, structural properties and rheology of acid-coagulated milk gels. Pages 105-122 in Cheese Chemistry, Physics and Microbiology. Vol. 1: General Aspects. 3rd ed. P. F. Fox, P. L. H. McSweeney, T. M. Cogan, and T. P. Guinee, ed. Elsevier Science \& Technology, London, UK.

Lucey, J. A., T. van Vliet, K. Grolle, T. Geurts, and P. Walstra. 1997. Properties of acid casein gels made by acidification with glucono- $\delta$ lactone. 2. Syneresis, permeability and microstructural properties. Int. Dairy J. 7:389-397.

Luyten, H., W. Kloek, and T. van Vliet. 1993. Yielding behavior of mixtures of xanthan and enzyme-modified galactomannans. Food Hydrocoll. 8:431-440.

Marshall, R. T. 1992. Standard Methods for the Examination of Dairy Products. 16th ed. American Public Health Association, Washington, DC.

Meilgaard, M., G. V. Civille, and B. T. Carr. 1999. Sensory Evaluation Techniques. 3rd ed. CRC Press, Boca Raton, FL.

Michalski, M. C., V. Briard, and F. Michel. 2001. Optical parameters of milk fat globules for laser light scattering measurements. Lait 81:787-796.

Montgomery, D. C. 2005. Design and Analysis of Experiments. 6th ed. John Wiley \& Sons Inc., New York, NY.

Mullen, L., and D. M. Ennis. 1979. Rotatable design in product development. Food Technol. 33:74-75. 78-80.

Nöbel, S., C. Kern, A. Sonne, B. Bähler, and J. Hinrichs. 2016. Apparent voluminosity of casein micelles in the temperature range $35-70^{\circ} \mathrm{C}$. Int. Dairy J. 59:80-84.

Park, Y. W. 2000. Comparison of mineral and cholesterol composition of different commercial goat milk products manufactured in USA. Small Rumin. Res. 37:115-124.

Phadungath, C. 2003. A study of structure development in Cream cheese and the impact of processing conditions on cheese texture, 
and sensory properties. MS thesis. Department of Food Science, University of Wisconsin-Madison.

Sanchez, C., J.-L. Beauregard, M. Bride, W. Buchheim, and J. Hardy. 1996. Rheological and microstructural characterization of double cream cheese. Nahrung 40:108-116.

Sanchez, C., J.-L. Beauregard, M.-H. Chassagne, J. J. Bimbenet, and J. Hardy. 1994a. Rheological and textural behaviour of double cream cheese. Part I: Effect of curd homogenization. J. Food Eng. 23:579-594.

Sanchez, C., J.-L. Beauregard, M.-H. Chassagne, A. Duquenoy, and J. Hardy. 1994b. Rheological and textural behaviour of double cream cheese. Part II: Effect of curd cooling rate. J. Food Eng. 23:595-608.

Schulz-Collins, D., and B. Senge. 2004. Acid and acid/rennet-curd cheeses. Part A: Quark, cream cheese and related varieties. Pages 301-328 in Cheese Chemistry, Physics and Microbiology. Vol. 2: Major Cheese Groups. 3rd ed. Elsevier Science \& Technology, London, UK.

Tamime, A. Y., and R. K. Robinson. 1999. Yoghurt-Science and Technology. Woodhead Publishers, Cambridge, UK.
Tomas, A., D. Paquet, J.-L. Courthaudon, and D. Lorient. 1994. Effect of fat and protein contents on droplet size and surface protein coverage in dairy emulsions. J. Dairy Sci. 77:413-417.

van Vliet, T. 1988. Rheological properties of filled gels. Influence of filler matrix interaction. Colloid Polym. Sci. 266:518-524.

Walstra, P., T. J. Geurts, A. Noomen, A. Jellema, and M. A. J. S. van Boekel. 1999. Dairy Technology: Principles of Milk Properties and Principles. Marcel Dekker, New York, NY.

Wendin, K., M. Langton, L. Caous, and G. Hall. 2000. Dynamic analyses of sensory and microstructural properties of cream cheese. Food Chem. 71:363-378.

Wilbey, R. A. 2002. Homogenization of milk. Pages 1346-1349 in Encyclopedia of Dairy Sciences. Vol. 3. H. Roginski, J. W. Fuquay, and P. F. Fox, ed. Academic Press, San Diego, CA.

Xiong, Y. L., J. M. Aguilera, and J. E. Kinsella. 1991. Emulsified milkfat effects on rheology of acid-induced milk gels. J. Food Sci. $56: 920-925$. 